(c) American Dairy Science Association, 2003.

\title{
The Effect of Reducing Alfalfa Haylage Particle Size on Cows in Early Lactation
}

\author{
P. J. Kononoff ${ }^{1}$ and A. J. Heinrichs ${ }^{2}$ \\ Department of Dairy and Animal Science, \\ Pennsylvania State University, \\ University Park, PA 16802
}

\section{ABSTRACT}

The objective of this experiment was to evaluate effects of reducing forage particle size on cows in early lactation based on measurements of the Penn State Particle Separator (PSPS). Eight cannulated, multiparous cows averaging $19 \pm 4 \mathrm{~d}$ in milk and $642 \pm 45 \mathrm{~kg}$ BW were assigned to one of two $4 \times 4$ Latin Squares. During each of the 23-d periods, animals were offered one of four diets, which were chemically identical but included alfalfa haylage of different particle size; short (SH), mostly short (MSH), mostly long (MLG), and long (LG). Physically effective neutral detergent fiber (peNDF) was determined by measuring the amount of neutral detergent fiber retained on a $1.18 \mathrm{~mm}$ screen and was similar across diets $(25.7,26.2,26.4,26.7 \%)$ but the amount of particles $>19.0 \mathrm{~mm}$ significantly decreased with decreasing particle size. Reducing haylage particle size increased dry matter intake linearly (23.3, $22.0,20.9,20.8 \mathrm{~kg}$ for SH, MSH, MLG, LG, respectively). Milk production and percentage fat did not differ across treatments averaging $35.5 \pm 0.68 \mathrm{~kg}$ milk and $3.32 \pm 0.67 \%$ fat, while a quadratic effect was observed for percent milk protein, with lowest values being observed for LG. A quadratic effect was observed for mean rumen $\mathrm{pH}(6.04,6.15,6.13,6.09)$, while A:P ratio decreased linearly $(2.75,2.86,2.88,2.92)$ with decreasing particle size. Total time ruminating increased quadratically (467, 498, 486, $468 \mathrm{~min} / \mathrm{d}$ ), while time eating decreased linearly $(262,253,298,287 \mathrm{~min} / \mathrm{d})$ with decreasing particle size. Both eating and ruminating per unit of neutral detergent fiber intake decreased with reducing particle size $(35.8,36.7,44.9,45.6 \mathrm{~min} / \mathrm{kg} ; 19.9,23.6$, $23.5,23.5 \mathrm{~min} / \mathrm{kg}$ ). Although chewing activity was

Received July 12, 2002.

Accepted October 20, 2002.

Corresponding author: A. J. Heinrichs, e-mail: ajh@psu.edu.

${ }^{1}$ Current address: Renaissance Nutrition, Inc., Post Office Box \#229, 481 Frederick Road, Roaring Spring, PA, 16673.

${ }^{2}$ Corresponding author address: A. J. Heinrichs, Department of Dairy and Animal Science, 324 Henning Building, University Park, PA 16802, phone (814) 863-3916, Fax (814) 863-7442, email: ajh@psu.edu. closely related to forage particle size, effects on rumen $\mathrm{pH}$ were small, indicating factors other than particle size are critical in regulating $\mathrm{pH}$ when ration neutral detergent fiber met recommended levels. Feeding alfalfa haylage based rations of reduced particle size resulted in animals consuming more feed but did not affect milk production.

(Key words: rumen, effective fiber, $\mathrm{pH}$, and rumination)

Abbreviation key: BWCH = body weight change, $\mathbf{D M D}=$ dry matter digestibility, $\mathbf{L D R}=$ liquid dilution rate, $\mathbf{L G}=$ long treatment containing long harvested haylage, $\mathbf{M S H}=$ intermediate short treatment composed of $1 / 3$ parts LG, $2 / 3$ parts SH, MLG = intermediate long composed of $2 / 3$ parts $L G, 1 / 3$ parts $\mathrm{SH}$. peNDF = physically effective neutral detergent fiber, PSPS = Penn State Particle Separator, RDOM = rumen degradable organic matter, $\mathbf{S}_{\mathbf{g m}}=$ geometric standard deviation, $\mathbf{S H}=$ short treatment containing rechopped alfalfa haylage, $\mathbf{T C}=$ total chewing activity, $\mathbf{T L C}=$ theoretical length of cut, $\mathbf{X}_{\mathbf{g m}}=$ geometric mean length.

\section{INTRODUCTION}

Ruminants require forage fiber in coarse physical form (NRC, 2001). Increasing fiber level and forage particle size has been shown to effectively increase chewing activity resulting in increased saliva flow, rumen $\mathrm{pH}$, acetate-to-propionate ratio and milk fat levels (Norgaard 1983; Beauchemin et al., 1997). Although impaired rumen fermentation and function can result when cattle are fed rations lacking in physical structure, excessive amounts of long, coarse fiber may also limit intake and digestibility, ultimately affecting energy balance of the animal (Allen, 2000).

Energy requirements are highest for cows in early lactation (NRC, 2001). During this time attempts are made to elevate energy intake through either feeding a ration of higher energy density or by increasing DMI (Woodford and Murphy, 1988; Kertz et al., 1991). Distension of the reticulo-rumen has been identified as one factor associated with satiety in ruminants with the magnitude of its effect dependent upon the energy re- 
quirement of the animal or the filling effect of the diet (Allen, 2000). Feeds of longer particle size usually result in greater fill because of a slower rate of passage limiting DMI through distension (Gherardi, et al., 1992). It has been suggested that reducing diet particle size during this time could positively affect DMI because the time required for rumination decreases (Allen, 2000). Decreasing forage particle size as a means to increase intake in cows during early lactation has been evaluated (Woodford and Murphy, 1988) using different forms of alfalfa hay, but the effects of haylage chop length is less understood and potential negative effects associated with rumen fermentation are not known.

Current NRC guidelines (NRC, 2001) have proven useful in defining animal requirements and feed composition but do not provide detailed recommendation of ration physical form. The concept of effective fiber was created to amalgamate the chemical characteristics and particle size of the forage, and to quantify its value to rumen function (Mertens, 2000). Although there have been numerous studies designed to examine the effective fiber requirements of dairy cattle, relatively few have been designed using cows in early lactation. In addition, in order to formulate ration particle size recommendations, studies must be designed to determine how reduction in particle size may affect intake and rumen function. Chewing and rumination are known accurate measurements of the roughage characteristics for ruminant diets (Balch 1971; Sudweeks et al., 1981). Physically effective NDF (peNDF) is defined as that dietary fiber source which effectively stimulates rumination and salivation (Mertens, 1997). Poppi et al. (1985) determined that particles that were retained on a sieve measuring $1.18 \mathrm{~mm}$ pass out of the rumen slower than those, which are not retained. Mertens (1997) suggests that in order for particles $>1.18 \mathrm{~mm}$ to pass out of the rumen they would have to be reduced through comminution and as a result these particles would stimulate more saliva secretion than those $<1.18 \mathrm{~mm}$.

The ability to routinely measure ration particle size has been difficult until introduction of The Penn State Particle Separator (PSPS). Based on properties of the ASAE Standard (S424) of forage particle size determination, the PSPS is a quick and cost effective method of particle size analysis. Using the PSPS a particle distribution is determined by separating particles according to size; those $>19.0 \mathrm{~mm}$, those between 19.0 and $8.0 \mathrm{~mm}$, and those $<8.0 \mathrm{~mm}$ (Lammers et al., 1996). With the construction of an additional square meshed screen comprised of nominal size openings of $1.18 \mathrm{~mm}$ the PSPS is capable of making the peNDF measurements proposed by Mertens (1997).

The objective of the following experiment is to determine the effect of forage particle size on DMI, chewing
Table 1. Nutrient composition and fermentation measures for alfalfa haylage.

\begin{tabular}{lcl}
\hline & Mean & SEM \\
\hline DM & 33.5 & 2.8 \\
CP & 21.9 & 2.1 \\
Soluble Protein & 15.1 & 1.1 \\
Ether Extract & 3.9 & 0.7 \\
NDF & 42.9 & 3.2 \\
NDIN & 2.3 & 3.0 \\
ADF & 36.9 & 3.4 \\
Lignin & 7.0 & 1.2 \\
TNC $^{2}$ & 1.6 & 0.4 \\
NFC & 22.7 & 1.6 \\
Ca & 2.3 & 0.6 \\
P & 0.25 & 0.01 \\
Mg & 0.23 & 0.007 \\
K & 2.9 & 0.03 \\
pH & 4.7 & 0.3 \\
Ammonia & 2.8 & 0.8 \\
Lactic acid & 5.9 & 2.2 \\
Acetic acid & 0.82 & 0.04 \\
Butyric acid & $<0.01$ & $\ldots$ \\
Propionic acid & $<0.01$ & $\ldots$ \\
Isobutyric acid & $<0.01$ & $\ldots$ \\
\hline
\end{tabular}

${ }^{1} \mathrm{TNC}=$ Total nonstructural carbohydrates (Smith, 1981).

${ }^{2} \mathrm{NFC}=$ Nonfiber carbohydrate calculated by difference $100-$ $(\% \mathrm{NDF}+\% \mathrm{CP}+\% \mathrm{Fat}+\% \mathrm{Ash})$.

activities, and rumen fermentation in early lactation cows. It is hypothesized that rations of finest particle size may be consumed at greatest amounts but result in lowest chewing activity and rumen $\mathrm{pH}$.

\section{MATERIALS AND METHODS}

\section{Forage, Animals and Experimental Design}

Alfalfa haylage was harvested in midbloom stage using a self-propelled forage harvester (John Deere, model 6750 ) set at $22.3 \mathrm{~mm}$ theoretical length of cut (TLC). The chopped material was then ensiled in a bunker type system for approximately $100 \mathrm{~d}$ and designated "long forage." Every second day during the course of the experiment, haylage was re-chopped twice using a pull type forage harvester (New Holland, model 900) set at $4.8 \mathrm{~mm}$ TLC, stored at $4^{\circ} \mathrm{C}$ and was designated "short forage." Table 1 contains chemical composition and physical characteristics of the alfalfa haylage.

Eight cannulated lactating multiparous Holstein cows averaging $19 \pm 4 \mathrm{~d}$ DIM and weighing $642 \pm 45$ $\mathrm{kg}$ were randomly assigned to one of two $4 \times 4$ Latin Squares. During each of the $23 \mathrm{~d}$ periods animals were offered one of four TMR that were chemically identical but differed in forage particle size. Diets were composed of either long (LG) or short (SH) haylage or as in the case of intermediate treatments, mixtures of these diets. Mostly long (MLG) was composed of $2 / 3$ parts LG, 1/3 parts SH TMR (DM basis); while mostly short 
(MSH) was composed of $1 / 3$ parts LG, $2 / 3$ parts $\mathrm{SH}$ TMR (DM basis). Animals were housed in individual stalls and milked at 0700 and $1900 \mathrm{~h}$. Cows were fed at $0800 \mathrm{~h}$ for ad libitum consumption to allow for approximately $5.0 \%$ refusal. The experimental cows were cared for and maintained according to the guidelines stipulated by the Pennsylvania State University Animal Care Committee.

\section{Forage and TMR Chemical and Analysis}

Samples of feed were collected twice weekly and orts were collected on $\mathrm{d} 15$ and 16 as well as the last $3 \mathrm{~d}$ of each period. Collected samples were immediately frozen $\left(-20^{\circ} \mathrm{C}\right)$ and stored for further analysis. Samples were then dried at $55^{\circ} \mathrm{C}$ in a forced air oven and ground (1 mm screen; Wiley mill, Aurthur A. Thomas Co., Philadelphia, PA). All feed and forage samples were analyzed in duplicate for moisture (AOAC 1990), Kjeldahl nitrogen (CP) (AOAC 1990) using a Kjetec 1030 auto analyzer, ether extract (AOAC 1990), calcium and phosphorus (AOAC 1984) and percent organic matter (OM) (AOAC 1984). Neutral detergent fiber (NDF) (Van Soest et al., 1991), acid detergent fiber (ADF) (AOAC 1990), acid detergent lignin (ADL) (AOAC 1990) were analyzed according to the procedure of Van Soest et al. (1991). Neutral detergent insoluble nitrogen (NDIN) and acid detergent insoluble nitrogen (ADIN) were analyzed on NDF and ADF residues (AOAC 1990). Heat stable alpha-amylase (number A3306; Sigma Chemical Co., St. Louis, MO) was included in the NDF procedure (100 $\mu \mathrm{l}$ per $0.50 \mathrm{~g}$ of sample). Total nonstructural carbohydrates (TNC) was determined according to the procedure of Smith, (1981) but modified to use ferricyanide as a colorimetric indicator. All ort samples were analyzed in duplicate for ADF, ash, CP, ether extract, moisture, NDF, and TNC.

\section{Chewing Activity}

Eating and ruminating activities were measured during d 15 and 16 of each period using Graze Jaw Movement Analysis Software of the IGER Behavior Recorder (Ultra Sound Advice, London) described by Rutter et al. (1997). Data were expressed as daily eating, ruminating, or total chewing activity (TC) by calculating the sum of eating and ruminating time over a $24 \mathrm{~h}$ period. Activities per unit of DM and NDF intake were calculated by dividing total minutes or number of bites by the mean of the activity measured. Total number of eating and ruminating bouts were also measured. Ruminating bouts were easily determined as regular activity pattern characterized with a 5 - to 10 -s period between boli when no jaw movements occurred. An eating bout was defined as eating activity occurring for at least five minutes. Eating bouts were separated if ten or more minutes of inactivity was observed between adjacent observations.

\section{Flow and Digestibility Markers and Apparent Digestability}

Particulate (forage) and liquid passage rates were determined using $\mathrm{Yb}_{3} \mathrm{Cl} 6 \mathrm{H}_{2} \mathrm{O}$ and Co-EDTA as described by Lykos et al. (1996). Prior to the AM feeding on $\mathrm{d} 17$ of each period, $5 \mathrm{~g}$ of bound $\mathrm{Yb}$ marked forage (average $\mathrm{Yb}$ concentration of $22 \mathrm{mg} / \mathrm{g}$ of DM) was pulse dosed through the ruminal cannula, mixed with ruminal digesta by hand, and followed by a pulse dose of $\mathrm{Co}$ (10 $\mathrm{g}$ of Co-EDTA dissolved in $1 \mathrm{~L}$ of tap water) for measurements of liquid passage. Solid and liquid passage rates were then calculated according to Grovum and Williams (1973).

Beginning on d 9 of each period, at 0800 and $2000 \mathrm{~h}$, one capsule containing $5 \mathrm{~g}$ of $\mathrm{Cr}_{2} \mathrm{O}_{3}$ was placed in the dorsal area of the rumen via the cannula for measurements of apparent total tract digestibility. Beginning at on d 17, approximately $250 \mathrm{~g}$ of fecal material was collected at $0,6,12,18,24,25,32,38.5,43,50,52,58$, $70,76,78,84,90,96,102,118 \mathrm{~h}$ and stored at $-20^{\circ} \mathrm{C}$. Samples were then dried at $55^{\circ} \mathrm{C}$ in a forced air oven, ground (1 mm screen; Wiley mill, Aurthur A. Thomas Co., Philadelphia, PA), and composited by cow and period. All fecal samples were analyzed in duplicate for moisture, ash, CP, NDF, ADF, TNC, EE, and NFC. Whole diet TDN concentration was determined using apparent digestibility of $\mathrm{CP}, \mathrm{EE}, \mathrm{NFC}, \mathrm{NDF}$ components of the whole diet (Weiss et al., 1992). Based on these values, production levels of $\mathrm{DE}, \mathrm{ME}$ and $\mathrm{NE}_{\mathrm{L}}$ were calculated as outlined by NRC (2001).

\section{Ruminal and Blood Sampling}

Beginning on $\mathrm{d} 17$ of each period ruminal contents were collected from the dorsal, ventral, and caudal area in the rumen at $0,1.5,3.5,5.5,8.5,11.5,14.5,18,21.5$, and $24.5 \mathrm{~h}$, beginning prior to Co dosing $(0 \mathrm{~h})$. Collected digesta was mixed by hand and filtered through four layers of cheesecloth. Rumen liquid $\mathrm{pH}$ determination was immediately determined by using a hand held $\mathrm{pH}$ electrode (model M90, Corning Inc., Corning NY). Approximately $15 \mathrm{ml}$ of filtered liquid was then placed into bottles containing $3 \mathrm{ml}$ of $25 \%$ metaphosphoric acid and $3 \mathrm{ml}$ of $0.6 \% 2$-ethyl butyric acid (internal standard) and stored at $-20^{\circ} \mathrm{C}$. Samples were later centrifuged three times at $4,000 \times \mathrm{g}$ for $30 \mathrm{~min}$ at $4^{\circ} \mathrm{C}$ to obtain a clear supernatant that was analyzed for ammonia using a phenol-hypochlorite assay (Broderick and Kang, 
1980) and VFA concentration using gas chromatography (Yang and Varga, 1989). Additionally, $50 \mathrm{ml}$ of rumen liquid was collected for Co analysis using the procedure described by Hart et al. (1984) (atomic absorption; Instrumentation Laboratories, model 22, aa/ ae spectrophotometer, Allied Analytical Systems, Waltham, MA). Ruminal samples for $\mathrm{Yb}$ determination were collected from the dorsal, ventral and caudal areas in the rumen at $0,1.5,3.5,5.5,8.5,11.5,14.5,18,21.5$, $24.5,28,31,37,40,46,52,60,72,78,87$, and $96 \mathrm{~h}$ after dosing, mixed by hand and filtered through four layers of cheesecloth. Any ruminal contents left after sample collection was repacked back into the rumen. Approximately 200 to $250 \mathrm{~g}$ of solids were placed in plastic bags and stored at $-20^{\circ} \mathrm{C}$. Samples were then freeze dried, ground in a Wiley Mill through a $1.0 \mathrm{~mm}$ screen (A.H. Thomas, Philadelphia, PA) and analyzed for $\mathrm{Yb}$ using atomic absorption spectroscopy.

The last day of each period and $4 \mathrm{~h}$ after feeding, approximately $500 \mathrm{ml}$ ruminal samples from the dorsal, ventral and caudal areas in the rumen and fecal samples were collected and weighed for determination of DM, NDF and particle size. The rumen of each animal was then emptied into large plastic bins and mixed thoroughly. Total digesta amounts were weighed and three $500 \mathrm{~mL}$ samples were collected and frozen at $-20^{\circ} \mathrm{C}$. All remaining digesta was manually repacked into the rumen of each animal. On $d 17$ at $1000 \mathrm{~h}$ of each period blood samples were collected from the tail vein of each animal. Blood samples were collected in tubes with sodium heparin for NEFA analysis (Wako NEFA C kit no. 990-75401; Wako Chemicals USA, Inc., Richmond, VA).

\section{Particle Size Analysis}

The PSPS was used to measure particle size for both forage and TMR as described by Kononoff et al. (2002). peNDF was estimated by multiplying NDF concentration of the TMR by the proportion of particles $>1.18$ $\mathrm{mm}$ (Mertens, 1997). Particle size of feed digesta and fecal samples was determined using wet sieving techniques as described by Beauchemin et al. (1997) using an Analysette 3 PRO Vibratory Sieve Shaker (Fritsch, Oberstein, Germany). Approximately $30 \mathrm{~g}$ of wet material was soaked in $1 \mathrm{~L}$ of distilled water for 10 minutes and then placed on a series of stacked sieves arranged in descending size and shaken for $10 \mathrm{~min}$. Subsequent sieving material was removed from each sieve and dried in a forced air oven at $55^{\circ} \mathrm{C}$ to determine the amount of dry matter retained on each sieve. Percent of dry matter retained on each sieve, geometric mean $\left(\mathbf{X}_{\mathbf{g m}}\right)$ and standard deviation $\left(\mathbf{S}_{\mathbf{g m}}\right)$ were calculated as outlined by the ASAE, 2001 (S424).
Table 2. Particle size distribution, geometric mean $\left(\mathrm{X}_{\mathrm{gm}}\right)$ and standard deviation $\left(\mathrm{S}_{\mathrm{gm}}\right)$ for ensiled and rechopped alfalfa haylage as measured by the Penn State Particle Separator.

\begin{tabular}{llll}
\hline & Ensiled & Rechopped & SEM \\
\hline \% DM retained & & & \\
$>19.0 \mathrm{~mm}$ & 61.5 & 13.7 & 5.9 \\
$19.0-8.0 \mathrm{~mm}$ & 26.2 & 51.7 & 4.1 \\
$8.0-1.18 \mathrm{~mm}$ & 11.2 & 32.5 & 2.0 \\
$<1.18 \mathrm{~mm}$ & 1.1 & 2.1 & 0.3 \\
$\mathrm{X}_{\mathrm{gm}}(\mathrm{mm})^{1}$ & 18.1 & 8.9 & 1.4 \\
$\mathrm{~S}_{\mathrm{gm}}(\mathrm{mm})^{2}$ & 2.1 & 2.2 & 0.1 \\
\hline
\end{tabular}

${ }^{1} \mathrm{X}_{\mathrm{gm}}=$ Geometric mean length as calculated by the ASAE (2001).

${ }^{2} \mathrm{~S}_{\mathrm{gm}}=$ Standard deviation as calculated by ASAE (2001).

\section{Milk Production}

Milk production was measured and recorded daily from d 15 to 23 of each period. On d 15, 16, 19, and 20 milk samples were collected and preserved using 2bromo-2-nitropropane-1,3 diol. Milk samples were analyzed for milk fat and true protein by the Pennsylvania DHIA milk testing laboratory (AOAC, 1990) using Infrared spectrophotometry (Foss 605B Milk-Scan; Foss Electric, Hillerød, Denmark).

\section{Statistical Analyses}

Data were analyzed as a replicated $4 \times 4$ Latin Square with model fixed effects for square, cow within square, period, and treatment included in the model. The first order autoregressive covariance structure $(\operatorname{AR}(1))$ and the MIXED procedure of SAS (SAS/STAT, 1999; Version 8.1) were used to analyze all data. Linear, quadratic, and cubic orthogonal contrasts were tested using the CONTRAST statement of SAS. Repeated measurements of rumen ammonia, $\mathrm{pH}$, and VFA concentration were analyzed by including a REPEATED model statement, as well as a term for time and interaction for treatment by time. Square by treatment interaction was tested but was not significant therefore was dropped from the model. Significance was declared at $P \leq 0.05$ and trends are discussed at $P \leq 0.10$. All means presented are least squares means.

\section{RESULTS}

\section{TMR Particle Size and Effective Fiber}

Chemical and physical description of alfalfa haylage included in the experiment is presented in Tables 1 and 2; total ration chemical composition and physical analysis is presented in Tables 3 and 4 . Ration particle size reflected the amount of rechopped forage included in the treatments. Rechopping forage resulted in less material being retained on the $19.0 \mathrm{~mm}$ screen but 
Table 3. Ingredient and nutrient composition of total mixed rations.

\begin{tabular}{|c|c|c|c|}
\hline & SHORT & LONG & SEM \\
\hline \multicolumn{4}{|l|}{ Diet Ingredients } \\
\hline Alfalfa haylage & 50.0 & 50.0 & $\ldots$ \\
\hline Ground Corn & 30.1 & 30.1 & $\ldots$ \\
\hline Soybeans & 1.75 & 1.75 & $\ldots$ \\
\hline Distillers Corn & 5.75 & 5.75 & $\ldots$ \\
\hline Wheat middlings & 5.28 & 5.28 & $\ldots$ \\
\hline Soyhulls & 3.43 & 3.43 & $\ldots$ \\
\hline Gluten Meal & 0.88 & 0.88 & $\ldots$ \\
\hline Feather Meal & 0.29 & 0.29 & $\ldots$ \\
\hline Blood Meal & 0.29 & 0.29 & $\ldots$ \\
\hline Fish Meal & 0.29 & 0.29 & $\ldots$ \\
\hline Tallow & 0.73 & 0.73 & $\ldots$ \\
\hline Salt & 0.46 & 0.46 & $\ldots$ \\
\hline Calcium Phosphate & 0.31 & 0.31 & $\ldots$ \\
\hline Potassium Chloride & 0.07 & 0.07 & $\ldots$ \\
\hline Magnesium Oxide & 0.24 & 0.24 & $\ldots$ \\
\hline Limestone & 0.04 & 0.04 & $\ldots$ \\
\hline Trace Mineral Mix ${ }^{1}$ & 0.02 & 0.02 & $\ldots$ \\
\hline Vitamin $\mathrm{ADE}^{2}$ & 0.07 & 0.07 & $\ldots$ \\
\hline \multicolumn{4}{|l|}{ Chemical } \\
\hline Moisture, \% & 48.7 & 46.6 & 0.36 \\
\hline $\mathrm{CP}, \% \mathrm{DM}$ & 17.6 & 17.9 & 0.20 \\
\hline Soluble CP, \% DM & 9.3 & 9.7 & 0.35 \\
\hline $\mathrm{TNC}, \% \mathrm{DM}^{3}$ & 28.0 & 26.6 & 0.59 \\
\hline $\mathrm{NDF}, \% \mathrm{DM}$ & 32.4 & 31.0 & 0.44 \\
\hline $\mathrm{ADF}, \% \mathrm{DM}$ & 26.1 & 24.2 & 0.42 \\
\hline Ether extract, \% of DM & 3.4 & 3.5 & 0.08 \\
\hline $\mathrm{NFC}, \% \mathrm{DM}^{4}$ & 42.9 & 42.1 & 0.97 \\
\hline
\end{tabular}

${ }^{1}$ Contained $0.57 \%$ calcium, $1362.2 \mathrm{mg} / \mathrm{kg}$ cobalt, $40,816.3 \mathrm{mg} / \mathrm{kg}$ copper, $2,724.5 \mathrm{mg} / \mathrm{kg}$ iodine, $10,204.1$ $\mathrm{mg} / \mathrm{kg}$ iron, $1,222,449.0 \mathrm{mg} / \mathrm{kg}$ manganese, $15.8 \%$ sulfur, $122,450.0 \mathrm{mg} / \mathrm{kg}$ zinc.

${ }^{2}$ Contained $28,792.5 \mathrm{~K} \mathrm{IU} / \mathrm{kg}$ vitamin A, 7,198.5 KIU/kg vitamin D, 179,959.6 IU/kg vitamin E.

${ }^{3} \mathrm{TNC}=$ Total nonstructural carbohydrates (Smith, 1981).

${ }^{4} \mathrm{NFC}=$ Nonfiber carbohydrate calculated by difference $100-(\% \mathrm{NDF}+\% \mathrm{CP}+\% \mathrm{Fat}+\%$ Ash $)$.

Table 4. Effects of reducing alfalfa haylage particle size on TMR particle size distribution, NDF content and physically effective NDF (peNDF) values.

\begin{tabular}{|c|c|c|c|c|c|c|}
\hline & \multicolumn{4}{|c|}{ Treatment $^{1,2}$} & \multirow[b]{2}{*}{$P$-value } & \multirow[b]{2}{*}{ SEM } \\
\hline & SH & MSH & MLG & LG & & \\
\hline \multicolumn{7}{|l|}{ \% DM retained } \\
\hline$>19.0 \mathrm{~mm}$ & $3.0^{\mathrm{d}}$ & $12.3^{\mathrm{c}}$ & $21.9^{b}$ & $31.4^{\mathrm{a}}$ & $<0.01$ & 1.66 \\
\hline $19.0-8.0 \mathrm{~mm}$ & $28.3^{\mathrm{a}}$ & $24.8^{\mathrm{b}}$ & $21.1^{\mathrm{c}}$ & $17.5^{\mathrm{d}}$ & $<0.01$ & 0.72 \\
\hline $8.0-1.18 \mathrm{~mm}$ & $49.0^{\mathrm{a}}$ & $43.7^{\mathrm{b}}$ & $38.4^{\mathrm{c}}$ & $33.0^{\mathrm{d}}$ & $<0.01$ & 0.80 \\
\hline$<1.18 \mathrm{~mm}$ & 19.7 & 19.2 & 18.6 & 18.1 & 0.44 & 0.73 \\
\hline $\mathrm{X}_{\mathrm{gm}}(\mathrm{mm})^{3}$ & $4.1^{\mathrm{a}}$ & $4.8^{\mathrm{b}}$ & $5.7^{\mathrm{c}}$ & $6.8^{\mathrm{d}}$ & $<0.01$ & 0.25 \\
\hline $\mathrm{S}_{\mathrm{gm}}(\mathrm{mm})^{4}$ & $2.7^{\mathrm{a}}$ & $3.1^{\mathrm{b}}$ & $3.4^{\mathrm{c}}$ & $3.6^{\mathrm{d}}$ & $<0.01$ & 0.02 \\
\hline \multicolumn{7}{|l|}{$\% \mathrm{NDF}(\mathrm{DM})$} \\
\hline$>19.0 \mathrm{~mm}$ & $46.8^{\mathrm{a}}$ & $45.6^{\mathrm{a}}$ & $43.4^{\mathrm{a}, \mathrm{b}}$ & $41.6^{\mathrm{b}}$ & 0.01 & 1.10 \\
\hline $19.0-8.0 \mathrm{~mm}$ & $39.2^{\mathrm{a}}$ & $38.2^{\mathrm{a}, \mathrm{b}}$ & $36.6^{\mathrm{b}, \mathrm{c}}$ & $35.3^{\mathrm{c}}$ & $<0.01$ & 0.52 \\
\hline $8.0-1.18 \mathrm{~mm}$ & $30.1^{\mathrm{a}}$ & $29.1^{\mathrm{a}, \mathrm{b}}$ & $27.9^{b, c}$ & $26.8^{\mathrm{c}}$ & $<0.01$ & 0.60 \\
\hline$<1.18 \mathrm{~mm}$ & 24.1 & 24.5 & 24.6 & 24.7 & 0.73 & 0.35 \\
\hline peNDF $^{5}$ & 25.7 & 26.2 & 26.4 & 26.7 & 0.52 & 0.51 \\
\hline
\end{tabular}

${ }^{1} \mathrm{SH}=$ TMR containing short alfalfa haylage, $\mathrm{LG}=$ TMR containing long alfalfa haylage, $\mathrm{MSH}=\mathrm{TMR}$ composed of $1 / 3$ parts LG, $2 / 3$ parts SH TMR, MLG $=$ TMR composed of $2 / 3$ parts LG, 1/3 parts SH TMR.

${ }^{2}$ Means in the same row with different letters differ $(P \leq 0.05)$.

${ }^{3} \mathrm{X}_{\mathrm{gm}}=$ Geometric mean length as calculated by the ASAE (2001).

${ }^{4} \mathrm{~S}_{\mathrm{gm}}=$ Standard deviation as calculated by ASAE (2001).

${ }^{5}$ peNDF $=$ Physically effective NDF $=$ Ration NDF multiplied by amount of DM $>1.18 \mathrm{~mm}$. 
Table 5. Effects of reducing alfalfa haylage particle size on body weight, body weight change, and intake on cows in early lactation.

\begin{tabular}{|c|c|c|c|c|c|c|c|c|}
\hline & \multicolumn{4}{|c|}{ Treatment $^{1}$} & \multirow[b]{2}{*}{ SEM } & \multicolumn{3}{|c|}{ Contrast } \\
\hline & $\mathrm{SH}$ & $\mathrm{MSH}$ & MLG & LG & & Linear & Quadratic & Cubic \\
\hline $\mathrm{BW}, \mathrm{kg}$ & 667 & 667 & 665 & 661 & 16.6 & 0.21 & 0.65 & 0.99 \\
\hline $\mathrm{BWCH}, \mathrm{kg} / \mathrm{d}^{2}$ & 0.52 & 0.40 & 0.30 & 0.08 & 0.19 & 0.06 & 0.84 & 0.87 \\
\hline DMI, kg/d & 23.4 & 21.8 & 20.7 & 20.1 & 0.85 & $<0.01$ & $<0.01$ & 0.49 \\
\hline DMI, \% BW & 3.54 & 3.28 & 3.11 & 3.19 & 0.14 & $<0.01$ & 0.15 & 0.63 \\
\hline NDF intake, kg/d & 7.33 & 6.83 & 6.50 & 6.59 & 0.27 & $<0.01$ & 0.02 & 0.64 \\
\hline NDF intake, \% BW & 1.11 & 1.03 & 0.978 & 0.998 & 0.05 & $<0.01$ & $<0.01$ & 0.59 \\
\hline
\end{tabular}

${ }^{1} \mathrm{SH}=\mathrm{TMR}$ containing short alfalfa haylage, $\mathrm{LG}=\mathrm{TMR}$ containing long alfalfa haylage, $\mathrm{MSH}=\mathrm{TMR}$ composed of $1 / 3$ parts LG, $2 / 3$ parts SH TMR, MLG = TMR composed of $2 / 3$ parts LG, 1/3 parts SH TMR.

${ }^{2} \mathrm{BWCH}=$ Body weight change.

increased the amount of particles being retained on both the 8.0 and $1.18 \mathrm{~mm}$ screens of the PSPS. Although the proportion of DM retained on the pan increased with decreasing particle size, differences were not significant. Geometric mean decreased linearly as the amount of rechopped forage in the TMR decreased. The peNDF value, as measured by the PSPS decreased numerically with decreasing particle size but these differences were not significant.

\section{Intake and Chewing Activities}

Intake data for DM and NDF are presented in Table 5. As particle size decreased there was a significant increasing linear effect on DMI and NDFI when expressed as total amount per day or percentage of BW. The largest difference between diets in DMI occurred between the $\mathrm{SH}$ and $\mathrm{LG}$ diets $(3.37 \mathrm{~kg} / \mathrm{d} ; 17 \%)$ and between SH and MLG diets for NDFI $(0.83 \mathrm{~kg} / \mathrm{d} ; 13 \%)$. Feed refusal samples were analyzed for NDF to evaluate sorting in the feed bunk and particle size but no effect was observed ( $P>0.05$; data not shown).

The effect of haylage physical form on eating and ruminating activity is presented in Table 6 . The total number of eating bouts and ruminating bouts was not significantly affected by forage particle size however total number of ruminating bouts per kilogram of DM and NDFI significantly decreased with decreasing particle size. Daily total time spent eating significantly decreased linearly with decreasing particle size but a significant quadratic effect was observed for total time spent ruminating. Eating, ruminating, and TC activity per kilogram of DM and NDFI decreased linearly with particle size. Total number of eating chews per day and per kilogram of DM and NDF intake was not significantly affected by forage particle length. In contrast, a quadratic trend in the total number of ruminating chews per day was observed.

Daily eating patterns are illustrated in Figure 1. Diurnal eating patterns for $\mathrm{SH}, \mathrm{MSH}$, and MLG treat- ments appeared similar with highest activity at the hour of feeding $(0800 \mathrm{~h}$ ) however animals consuming LG treatments exhibited pronounced meal bouts at 1400,1500 , and $2300 \mathrm{~h}$ when compared to the other treatments.

\section{Apparent Digestibilities and Energy Utilization}

Apparent digestibility, measured $\mathrm{TDN}$ and $\mathrm{NE}_{\mathrm{L}}$ is presented in Table 7. Highest dry matter digestibility (DMD) was observed on rations of shortest particle size (66.5\%) and decreased linearly with lowest DMD (63.1\%) observed on diets of longest particle size. More specifically, apparent digestibility of $\mathrm{CP}$, TNC, ether extract, NFC increased linearly and NDF and OM digestibility tended to increase linearly with decreasing particle size. As a result of differences in digestibility between treatments, dietary content of both TDN and $\mathrm{NE}_{\mathrm{L}}$ tended to decrease linearly from the shortest ration $(65.8 \%, 1.57 \mathrm{Mcal} / \mathrm{kg})$ to the longest $(62.9 \%, 1.47$ $\mathrm{Mcal} / \mathrm{kg})$.

\section{Rumen Fill, Rate of Passage, Particle Size}

Rumen fill of total digesta, NDF and total DM and rate of passage is presented in Table 7 . No effect was observed in amount of rumen DM or NDF mass across treatments. No effect was observed for rumen liquid dilution rate (LDR) or solid passage rate averaging 16.4 and 4.15 percent per hour.

The effects of rechopping forage on the particle size of TMR, rumen digesta and fecal material is presented in Table 8. Rechopping forage had large effects on the particle size of TMR as $\mathrm{X}_{\mathrm{gm}}$ and the amount of DM > $1.18 \mathrm{~mm}$ decreased with reducing particle size. Effects on rumen digesta particle size were less pronounced however $\mathrm{X}_{\mathrm{gm}}$ tended to decrease with reduced particle size. In comparison, fecal $\mathrm{X}_{\mathrm{gm}}$ and percent of material retained on a 1.18-mm sieve was unaffected by ration particle size averaging $1.0 \mathrm{~mm}$ and $46.1 \%$ respectively. 
Table 6. Effects of reducing alfalfa haylage particle size on chewing activities on cows in early lactation.

\begin{tabular}{|c|c|c|c|c|c|c|c|c|}
\hline & \multicolumn{4}{|c|}{ Treatment $^{1}$} & \multirow[b]{2}{*}{ SEM } & \multicolumn{3}{|c|}{ Contrast } \\
\hline & $\mathrm{SH}$ & MSH & MLG & LG & & Linear & Quadratic & Cubic \\
\hline \multicolumn{9}{|l|}{ Bouts/d } \\
\hline Eating & 13.4 & 13.9 & 16.4 & 12.9 & 1.73 & 0.88 & 0.22 & 0.25 \\
\hline Ruminating & 15.3 & 16.5 & 16.3 & 17.2 & 1.23 & 0.26 & 0.88 & 0.58 \\
\hline \multicolumn{9}{|l|}{ Bouts/ kg DMI } \\
\hline Eating & 0.59 & 0.64 & 0.81 & 0.65 & 0.09 & 0.35 & 0.19 & 0.22 \\
\hline Ruminating & 0.67 & 0.76 & 0.80 & 0.85 & 0.07 & 0.04 & 0.54 & 0.85 \\
\hline \multicolumn{9}{|c|}{ Bouts/ kg NDFI } \\
\hline Eating & 1.88 & 2.05 & 2.60 & 2.09 & 0.31 & 0.35 & 0.20 & 0.24 \\
\hline Ruminating & 2.13 & 2.43 & 2.57 & 2.71 & 0.24 & 0.04 & 0.58 & 0.82 \\
\hline \multicolumn{9}{|l|}{ Min/d } \\
\hline Eating & 261.7 & 254.0 & 290.8 & 297.8 & 20.9 & 0.02 & 0.39 & 0.13 \\
\hline Ruminating & 460.2 & 504.7 & 477.9 & 479.1 & 21.8 & 0.54 & 0.02 & 0.03 \\
\hline $\mathrm{TC}^{2}$ & 723.4 & 758.9 & 768.3 & 776.7 & 31.7 & 0.08 & 0.35 & 0.74 \\
\hline \multicolumn{9}{|l|}{$\mathrm{Min} / \mathrm{Kg} \mathrm{DMI}$} \\
\hline Eating & 11.2 & 11.5 & 14.1 & 14.3 & 0.9 & $<0.01$ & 0.77 & 0.05 \\
\hline Ruminating & 19.9 & 23.6 & 23.5 & 23.5 & 1.2 & $<0.01$ & 0.13 & 0.35 \\
\hline $\mathrm{TC}^{2}$ & 31.2 & 35.2 & 37.5 & 37.9 & 1.6 & $<0.01$ & 0.04 & 0.98 \\
\hline \multicolumn{9}{|l|}{ Min/Kg NDFI } \\
\hline Eating & 35.8 & 36.7 & 44.9 & 45.6 & 2.9 & $<0.01$ & 0.92 & 0.06 \\
\hline Ruminating & 63.4 & 75.1 & 74.5 & 75.7 & 3.9 & $<0.01$ & $<0.01$ & 0.09 \\
\hline $\mathrm{TC}^{2}$ & 99.7 & 112.1 & 119.2 & 120.8 & 5.2 & $<0.01$ & 0.06 & 0.99 \\
\hline \multicolumn{9}{|l|}{ Chews/d } \\
\hline Eating & 6,140 & 6,172 & 7,444 & 6,904 & 1,090 & 0.33 & 0.69 & 0.38 \\
\hline Ruminating & 27,680 & 31,573 & 30,122 & 29,483 & 1,667 & 0.53 & 0.07 & 0.29 \\
\hline \multicolumn{9}{|l|}{ Chews/ Kg DMI } \\
\hline Eating & 264.5 & 287.0 & 359.5 & 332.5 & 44.4 & 0.12 & 0.45 & 0.35 \\
\hline Ruminating & 1,213 & 1,476 & 1,470 & 1,460 & 77 & 0.07 & 0.24 & 0.51 \\
\hline \multicolumn{9}{|c|}{ Chews/Kg NDFI } \\
\hline Eating & 841.6 & 908.6 & 1,138 & 1,066 & 141 & 0.11 & 0.50 & 0.36 \\
\hline Ruminating & 3,883 & 4,690 & 4,669 & 4,666 & 245 & 0.03 & 0.07 & 0.36 \\
\hline
\end{tabular}

${ }^{1} \mathrm{SH}=\mathrm{TMR}$ containing short alfalfa haylage, $\mathrm{LG}=\mathrm{TMR}$ containing long alfalfa haylage, $\mathrm{MSH}=\mathrm{TMR}$ composed of $1 / 3$ parts LG, $2 / 3$ parts SH TMR, MLG = TMR composed of $2 / 3$ parts LG, 1/3 parts SH TMR.

${ }^{2} \mathrm{TC}=$ Total chewing activity (minutes eating + minutes ruminating).

\section{Rumen pH, VFA, ammonia and Blood NEFA}

Effects of alfalfa haylage particle size on ruminal $\mathrm{pH}, \mathrm{VFA}$ and ammonia concentrations are presented in Table 9. Total concentration of VFA significantly increased linearly with reducing particle size from $149.3 \mathrm{~m} M / \mathrm{L}$ on $\mathrm{SH}$ to $136.0 \mathrm{~m} M / \mathrm{L}$ on $\mathrm{LG}$. The same significant effect was observed for concentrations of acetate, propionate, and butyrate while acetate to propionate ratio decreased linearly from 2.92 on LG to 2.75 on SH. There was a significant quadratic effect observed for mean rumen $\mathrm{pH}$ with highest values, 6.15 and 6.13 observed on MSH and MLG diets. Diurnal rumen $\mathrm{pH}$ appeared to be highest just prior to feeding and reached a minimum approximately two hours after evening milking and return to the barn (Figure 1). Rumen $\mathrm{pH}$ measurements for the MSH and MLG rations followed a similar pattern while animals consuming SH diets appeared to be flatter with less fluctuation compared to when consuming $\mathrm{LG}$ diets. Ruminal $\mathrm{NH}_{3}-\mathrm{N}$ was observed to be unaffected by diet, averaging $11.24 \mathrm{mg} /$ dl. No significant differences were observed in blood NEFA concentration.

\section{Milk Production, Composition and Body Weight Change}

Milk production, composition and body weight change (BWCH) are presented in Tables 5 and 10. Milk yield and 3.5\% FCM were similar across diets and averaged 35.5 and $35.2 \mathrm{~kg}$, respectively. Forage particle size did not affect either percent fat or yield averaging $3.31 \%$ and $1.2 \mathrm{~kg}$. Although no effect of forage particle size was observed on milk true protein yield, a quadratic effect was observed in percent true protein with LG resulting in lowest $(2.82 \%)$ values. Lastly, feeding rations of reduced forage particle size tended to result in a positive increase in body weight during experimental periods.

\section{DISCUSSION}

Based on a survey composed of over 800 samples, Heinrichs et al. (1999) reported that although TMR samples fed on commercial dairy farms typically contain $7 \%$ of the particles greater than $19.0 \mathrm{~mm}$ variation across herds is large. In the same study, a minimum 


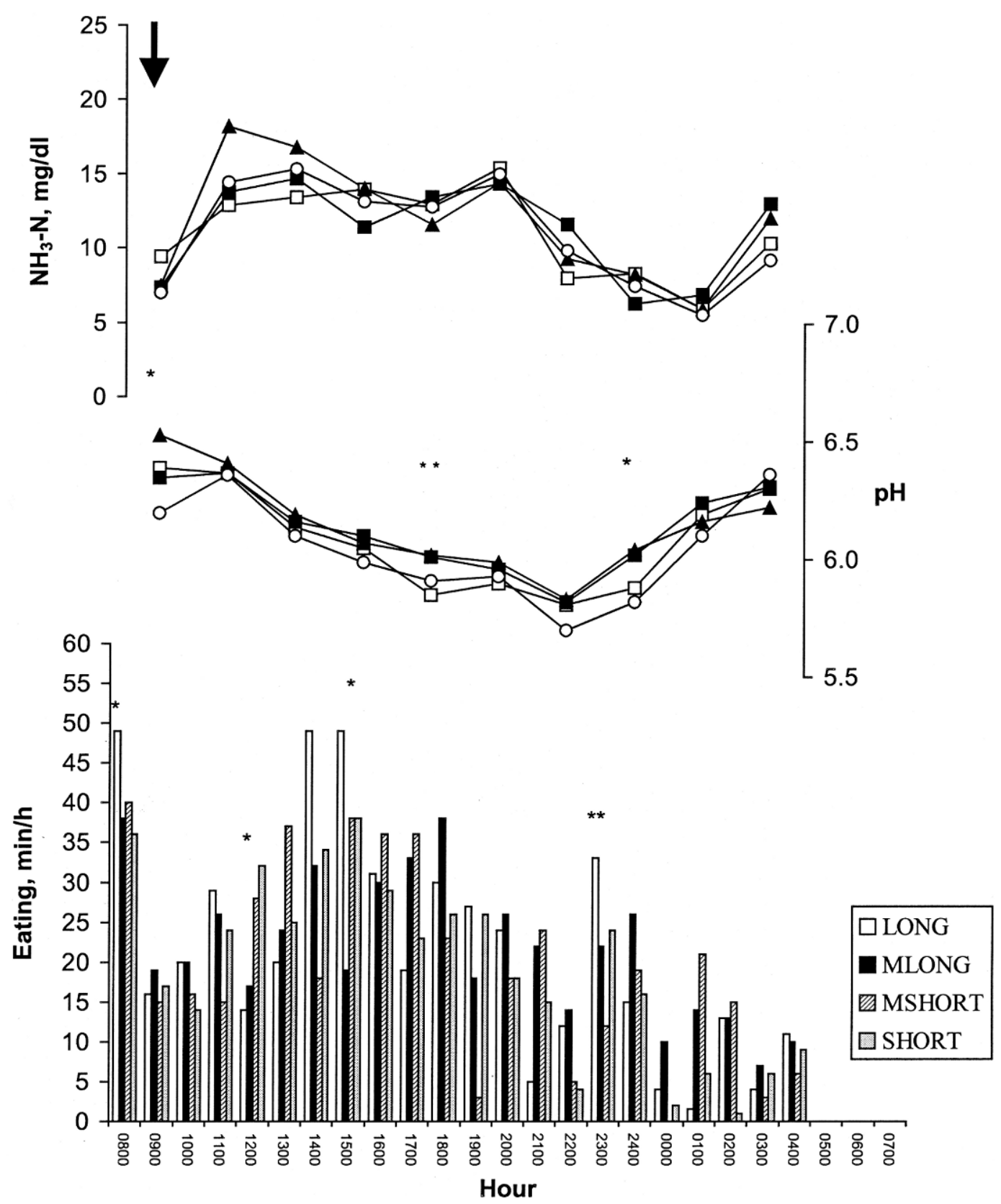

Figure 1. Effects of reducing alfalfa haylage particle size on daily rumen $\mathrm{pH}$ and $\mathrm{NH}_{3}-\mathrm{N}$ concentration and eating pattern in min/h for a 24 -h period for dairy cows LONG $(\square)$, MLONG $(\square)$, MSHORT $(\boldsymbol{\Delta})$ or SHORT $(\bigcirc)$. Arrow indicates feeding time $(* P \leq 0.05 ; * * P \leq 0.10)$.

of $1 \%$ and a maximum of $43 \%$ of the particles were observed to be greater that $19.0 \mathrm{~mm}$, thus the range of TMR particle size used in the current study is typical of that in use of commercial dairy farms.

Results of this study indicate that intake during early lactation may be increased by reducing forage particle size. These results are similar to some studies in which reducing forage particle size resulted in increased intake (Rodrique and Allen 1960; Jaster and Murphy
1983; Woodford and Murphy 1986; Fisher et al., 1994; Beauchemin et al., 1997), but are in contrast to others which report no observed differences (Grant et al., 1990; Colenbrander et al., 1991). Most studies reporting no effects include cows in midlactation that were likely meeting their energy requirements. In the current experiment cows in early lactation were used and energy status was improved, presumably through increased intake and digestibility, as feeding diets of reduced par- 
Table 7. The effect of reducing alfalfa haylage particle size on nutrient digestibility, calculated energy values, rumen fill and solid and liquid passage rate in cows in early lactation.

\begin{tabular}{|c|c|c|c|c|c|c|c|c|}
\hline & \multicolumn{4}{|c|}{ Treatment $^{1}$} & \multirow[b]{2}{*}{ SEM } & \multicolumn{3}{|c|}{ Contrast } \\
\hline & $\mathrm{SH}$ & MSH & MLG & LG & & Linear & Quadratic & Cubic \\
\hline \multicolumn{9}{|l|}{ Digestibility } \\
\hline $\mathrm{DM}, \%$ & 66.5 & 63.7 & 64.4 & 63.1 & 1.0 & 0.03 & 0.29 & 0.14 \\
\hline $\mathrm{OM}, \%$ & 68.4 & 66.0 & 66.9 & 65.4 & 1.0 & 0.06 & 0.52 & 0.15 \\
\hline $\mathrm{CP}, \%$ & 58.6 & 54.0 & 53.6 & 53.2 & 1.4 & 0.01 & 0.09 & 0.46 \\
\hline NDF, \% & 48.1 & 45.6 & 46.9 & 44.7 & 1.1 & 0.06 & 0.84 & 0.11 \\
\hline $\mathrm{ADF}, \%$ & 54.0 & 50.4 & 52.8 & 52.2 & 1.8 & 0.70 & 0.42 & 0.26 \\
\hline TNC, \% & 89.8 & 88.1 & 87.9 & 86.9 & 0.8 & 0.02 & 0.55 & 0.46 \\
\hline $\mathrm{EE}, \%$ & 58.4 & 54.1 & 53.5 & 52.9 & 1.3 & 0.01 & 0.09 & 0.47 \\
\hline $\mathrm{NFC}, \%^{2}$ & 88.4 & 87.5 & 87.5 & 86.5 & 1.5 & 0.39 & 0.96 & 0.78 \\
\hline TDN, $\%^{3}$ & 65.8 & 63.1 & 64.1 & 62.9 & 1.1 & 0.09 & 0.38 & 0.18 \\
\hline $\mathrm{NE}_{\mathrm{Lp}}, \mathrm{Mcal} / \mathrm{kg}^{4}$ & 1.57 & 1.48 & 1.51 & 1.47 & 0.03 & 0.07 & 0.33 & 0.16 \\
\hline \multicolumn{9}{|l|}{ Rumen Fill ${ }^{5}$} \\
\hline $\begin{array}{l}\text { Wet weight, kg } \\
\text { DM, }\end{array}$ & 73.3 & 70.08 & 76.6 & 71.9 & 4.5 & 0.87 & 0.86 & 0.23 \\
\hline$\%$ & 18.9 & 18.4 & 19.3 & 18.5 & 0.53 & 0.88 & 0.79 & 0.21 \\
\hline $\mathrm{Kg}$ & 13.5 & 14.2 & 13.6 & 13.6 & 0.96 & 0.91 & 0.77 & 0.69 \\
\hline \multicolumn{9}{|l|}{ NDF, } \\
\hline$\%$ & 60.4 & 58.2 & 57.6 & 58.6 & 1.1 & 0.25 & 0.22 & 0.96 \\
\hline $\mathrm{Kg}$ & 8.06 & 8.23 & 7.78 & 7.88 & 0.47 & 0.63 & 0.94 & 0.58 \\
\hline Liquid passage rate, $\% / \mathrm{h}$ & 16.5 & 16.2 & 17.2 & 15.7 & 1.0 & 0.73 & 0.53 & 0.35 \\
\hline Forage passage rate, $\% / \mathrm{h}$ & 4.06 & 4.39 & 4.0 & 4.06 & 0.23 & 0.54 & 0.47 & 0.15 \\
\hline
\end{tabular}

${ }^{1} \mathrm{SH}=\mathrm{TMR}$ containing short alfalfa haylage, $\mathrm{LG}=\mathrm{TMR}$ containing long alfalfa haylage, $\mathrm{MSH}=\mathrm{TMR}$ composed of 1/3 parts LG, 2/3 parts SH TMR, MLG = TMR composed of 2/3 parts LG, 1/3 parts SH TMR.

${ }^{2} \mathrm{NFC}=$ Nonfiber carbohydrate calculated by difference.

${ }^{3} \mathrm{TDN}(\%)=\mathrm{tdNFC}+\mathrm{tdCP}+(\mathrm{tdEE} \times 2.25)+\mathrm{tdNDF}$; where td denotes truly digestible fraction.

${ }^{4} \mathrm{NE}_{\mathrm{Lp}}(\mathrm{Mcal} / \mathrm{kg})=0.703 \times \mathrm{ME}_{\mathrm{p}}(\mathrm{Mcal} / \mathrm{kg})(\mathrm{NRC}, 2001)$.

${ }^{5}$ Manual empty.

ticle size tended to increase body weight gain and numerically decreased plasma NEFA concentration. Due to the experiment's cross over design it is not possible to completely attribute effects on $\mathrm{BWCH}$ to dietary treatments however together these observations suggest increased energy balance with feeding rations of reduced particle size.

In the present study, reducing alfalfa haylage particle size resulted in decreased chewing activities per unit of DM and NDF consumed and is similar to results reported by Beauchemin et al. (1994) and Grant et al. (1990). Chewing activity is the primary mechanism to reduce feed particle size and is central to both the nature of digestion and passage through the gastrointestinal tract. It is well established that increasing forage particle size increases chewing activity but relatively few studies have related these measurements to the PSPS. Our data suggests that increasing the proportion of particles $>19.0 \mathrm{~mm}$ may be a primary factor affecting chewing activity in dairy cattle fed diets containing alfalfa haylage as the forage source. In the current study the proportion of feed particles $>19.0 \mathrm{~mm}$ increased with increasing particle size while the proportion of particles $8.0-19.0 \mathrm{~mm}$ and $8.0-1.18 \mathrm{~mm}$ decreased with increasing particle size. The LG ration containing $31 \%$ of the particles $>19.0 \mathrm{~mm}$ resulted in the highest eating, ruminating, and total chewing activity per unit of DM and NDF intake as well as pronounced eating bouts at 1400, 1500 and $2300 \mathrm{~h}$. Although it follows that less time would be required for ruminating when a diet of short particle size is consumed, we are unable to explain why greatest time spent ruminating was observed on the MSH ration.

Changes in physical characteristics of the ration also resulted in effects on rumen VFA patterns. In animals consuming SH rations containing $3 \%$ of the particles $>19.0 \mathrm{~mm}$, digestibility and VFA concentration were highest but mean rumen $\mathrm{pH}$ was lowest indicating that substrate availability to rumen microbes increased with reduction in particle size. In the current study, reduction in particle size increased digestibility of all nutrients except ADF and NFC. Observed effects were likely a result of increased surface area available for microbial attack, ultimately resulting in a more rapid rate of rumen fermentation and increased intake (Chesson et al., 1995). Although depressed fiber digestibility has been observed in some studies when forage particle size is reduced, this is usually observed when a severe elevation in rate of passage is much greater than changes in rate of digestibility (Woodford and Murphy, 1988; Le Liboux and Peyraud, 1998). In the current study, reduction in haylage particle size did not affect 
Table 8. The effect of reducing alfalfa haylage particle size on particle size of feed, rumen digesta, and feces in cows in early lactation.

\begin{tabular}{|c|c|c|c|c|c|c|c|c|}
\hline & \multicolumn{4}{|c|}{ Treatment $^{1}$} & \multirow[b]{2}{*}{ SEM } & \multicolumn{3}{|c|}{ Contrast } \\
\hline & $\mathrm{SH}$ & MSH & MLG & LG & & Linear & Quadratic & Cubic \\
\hline \multicolumn{9}{|l|}{ Feed } \\
\hline \multicolumn{9}{|l|}{ Sieve, mm } \\
\hline 13.2 & 10.8 & 18.8 & 27.7 & 34.9 & 3.20 & $<0.01$ & 0.90 & 0.86 \\
\hline 6.7 & 10.4 & 9.0 & 7.6 & 6.1 & 0.53 & $<0.01$ & 0.97 & 0.96 \\
\hline 3.35 & 9.5 & 8.1 & 6.7 & 5.3 & 0.45 & $<0.01$ & 0.99 & 0.99 \\
\hline 1.18 & 38.0 & 34.1 & 29.6 & 26.2 & 1.99 & $<0.01$ & 0.90 & 0.87 \\
\hline 0.6 & 15.3 & 14.6 & 13.8 & 13.3 & 0.63 & 0.02 & 0.88 & 0.84 \\
\hline 0.15 & 16.0 & 15.4 & 14.6 & 14.2 & 0.37 & $<0.01$ & 0.82 & 0.76 \\
\hline$>1.18$ & 72.5 & 71.6 & 70.0 & 68.7 & 0.96 & $<0.01$ & 0.85 & 0.80 \\
\hline $\mathrm{X}_{\mathrm{gm}}(\mathrm{mm})^{2}$ & 2.1 & 2.4 & 2.9 & 3.4 & 0.25 & $<0.01$ & 0.78 & 0.82 \\
\hline $\mathrm{S}_{\mathrm{gm}}(\mathrm{mm})^{3}$ & 3.3 & 3.6 & 3.8 & 3.9 & 0.10 & $<0.01$ & 0.29 & 0.98 \\
\hline \multirow{2}{*}{\multicolumn{9}{|c|}{ Sieve, mm }} \\
\hline & & & & & & & & \\
\hline 13.2 & 17.9 & 8.2 & 18.6 & 24.7 & 3.67 & 0.06 & 0.06 & 0.09 \\
\hline 6.7 & 7.5 & 9.9 & 8.0 & 8.5 & 1.06 & 0.78 & 0.43 & 0.11 \\
\hline 1.18 & 39.1 & 50.4 & 37.1 & 32.6 & 3.1 & 0.02 & 0.03 & 0.02 \\
\hline 0.6 & 13.0 & 10.1 & 12.2 & 11.4 & 1.3 & 0.61 & 0.43 & 0.13 \\
\hline 0.15 & 22.4 & 21.5 & 24.2 & 22.8 & 0.51 & 0.09 & 0.64 & 0.003 \\
\hline$>1.18$ & 64.6 & 68.4 & 63.7 & 65.8 & 1.10 & 0.81 & 0.47 & 0.003 \\
\hline $\mathrm{X}_{\mathrm{gm}}(\mathrm{mm})^{2}$ & 2.1 & 2.1 & 2.3 & 2.5 & 0.16 & 0.06 & 0.36 & 0.73 \\
\hline $\mathrm{S}_{\mathrm{gm}}(\mathrm{mm})^{3}$ & 3.9 & 3.4 & 4.0 & 4.3 & 0.15 & 0.01 & 0.05 & 0.02 \\
\hline \multirow{2}{*}{\multicolumn{9}{|c|}{$\begin{array}{l}\text { Feces } \\
\text { Sieve mm }\end{array}$}} \\
\hline & & & & & & & & \\
\hline 6.67 & 2.75 & 3.27 & 4.44 & 2.96 & 1.1 & 0.13 & 0.96 & 0.45 \\
\hline 1.18 & 48.4 & 48.5 & 49.2 & 36.4 & 2.6 & 0.43 & 0.96 & 0.89 \\
\hline 0.6 & 9.46 & 10.8 & 10.1 & 13.2 & 1.3 & 0.33 & 0.70 & 0.18 \\
\hline 0.15 & 39.4 & 37.4 & 36.3 & 47.7 & 2.1 & 0.44 & 0.78 & 0.31 \\
\hline$>1.18$ & 46.4 & 46.0 & 46.3 & 45.7 & 2.7 & 0.89 & 0.98 & 0.87 \\
\hline $\mathrm{X}_{\mathrm{gm}}(\mathrm{mm})^{2}$ & 1.0 & 1.0 & 1.1 & 1.0 & 0.06 & 0.92 & 0.91 & 0.40 \\
\hline $\mathrm{S}_{\mathrm{gm}}(\mathrm{mm})^{3}$ & 2.9 & 2.9 & 3.0 & 3.0 & 0.08 & 0.24 & 0.85 & 0.89 \\
\hline
\end{tabular}

${ }^{1} \mathrm{SH}=\mathrm{TMR}$ containing short alfalfa haylage, $\mathrm{LG}=\mathrm{TMR}$ containing long alfalfa haylage, $\mathrm{MSH}=\mathrm{TMR}$ composed of 1/3 parts LG, 2/3 parts SH TMR, MLG = TMR composed of 2/3 parts LG, 1/3 parts SH TMR.

${ }^{2} \mathrm{X}_{\mathrm{gm}}=$ Geometric mean length as calculated by the ASAE (2001).

${ }^{3} \mathrm{~S}_{\mathrm{gm}}=$ Standard deviation as calculated by ASAE (2001).

rate of rumen outflow of either liquid or solid particles. ways affect solid or liquid passage rates. Although it These results are consistent with those of Yang et al. has been suggested feeds of longer particle size may (2001) who reported that rechopping forage did not al- limit intake as a result of a slower rate of passage and

Table 9. Effects of reducing alfalfa haylage particle size on ruminal $\mathrm{pH}$, concentration ammonia, VFA, and blood NEFA level on cows in early lactation.

\begin{tabular}{|c|c|c|c|c|c|c|c|c|}
\hline & \multicolumn{4}{|c|}{ Treatment $^{1}$} & \multirow[b]{2}{*}{ SEM } & \multicolumn{3}{|c|}{ Contrast } \\
\hline & $\mathrm{SH}$ & MSH & MLG & LG & & Linear & Quadratic & Cubic \\
\hline $\mathrm{pH}$ & 6.04 & 6.15 & 6.13 & 6.09 & 0.1 & 0.28 & $<0.01$ & 0.46 \\
\hline $\begin{array}{l}\text { Total VFA (mM/L) } \\
\text { VFA (mM/L) }\end{array}$ & 149.3 & 141.4 & 140.2 & 136.0 & 2.3 & $<0.01$ & 0.42 & 0.37 \\
\hline Acetate & 92.2 & 88.3 & 88.1 & 85.9 & 1.5 & $<0.01$ & 0.55 & 0.37 \\
\hline Propionate & 33.9 & 31.5 & 31.0 & 29.8 & 0.9 & $<0.01$ & 0.29 & 0.32 \\
\hline Isobutyrate & 1.43 & 1.41 & 1.37 & 1.30 & 0.1 & $<0.01$ & 0.37 & 0.86 \\
\hline Butyrate & 16.6 & 15.3 & 14.9 & 14.5 & 0.4 & $<0.01$ & 0.13 & 0.37 \\
\hline Isovalerate & 2.30 & 2.28 & 2.19 & 2.07 & 0.1 & $<0.01$ & 0.28 & 0.83 \\
\hline Valerate & 2.94 & 2.68 & 2.58 & 2.49 & 0.1 & $<0.01$ & 0.15 & 0.56 \\
\hline Acetate: Propionate & 2.75 & 2.86 & 2.88 & 2.92 & 0.1 & $<0.01$ & 0.08 & 0.24 \\
\hline $\mathrm{NH}_{3}-\mathrm{N}(\mathrm{mg} / \mathrm{dl})$ & 10.9 & 11.8 & 11.2 & 11.0 & 0.6 & 0.90 & 0.30 & 0.47 \\
\hline NEFA ( $\mu \mathrm{eq} / \mathrm{L})$ & 136.5 & 145.8 & 146.8 & 148.9 & 19.6 & 0.64 & 0.84 & 0.91 \\
\hline
\end{tabular}

${ }^{1} \mathrm{SH}=\mathrm{TMR}$ containing short alfalfa haylage, $\mathrm{LG}=\mathrm{TMR}$ containing long alfalfa haylage, $\mathrm{MSH}=\mathrm{TMR}$ composed of 1/3 parts LG, 2/3 parts SH TMR, MLG = TMR composed of 2/3 parts LG, 1/3 parts SH TMR. 
Table 10. Effects of reducing alfalfa haylage particle size on milk production and composition on cows in early lactation.

\begin{tabular}{|c|c|c|c|c|c|c|c|c|}
\hline & \multicolumn{4}{|c|}{ Treatment $^{1}$} & \multirow[b]{2}{*}{ SEM } & \multicolumn{3}{|c|}{ Contrast } \\
\hline & $\mathrm{SH}$ & MSH & MLG & LG & & Linear & Quadratic & Cubic \\
\hline Milk Yield & 36.0 & 35.3 & 34.8 & 36.0 & 1.6 & 0.68 & 0.11 & 0.39 \\
\hline $3.5 \% \mathrm{FCM}$ & 35.6 & 35.0 & 34.5 & 35.5 & 2.0 & 0.84 & 0.26 & 0.68 \\
\hline Fat \% & 3.38 & 3.27 & 3.31 & 3.31 & 0.14 & 0.67 & 0.47 & 0.65 \\
\hline Fat, Kg/d & 1.23 & 1.20 & 1.17 & 1.20 & 0.08 & 0.58 & 0.49 & 0.76 \\
\hline Protein \% & 2.90 & 2.91 & 2.93 & 2.82 & 0.04 & 0.15 & 0.03 & 0.32 \\
\hline Protein, Kg/d & 1.05 & 1.07 & 1.03 & 1.03 & 0.05 & 0.28 & 0.65 & 0.28 \\
\hline
\end{tabular}

${ }^{1} \mathrm{SH}=\mathrm{TMR}$ containing short alfalfa haylage, $\mathrm{LG}=\mathrm{TMR}$ containing long alfalfa haylage, $\mathrm{MSH}=\mathrm{TMR}$ composed of $1 / 3$ parts LG, $2 / 3$ parts SH TMR, MLG = TMR composed of $2 / 3$ parts LG, 1/3 parts SH TMR.

greater rumen fill, in the current study no effects were observed in either passage rate or rumen DM and NDF pool suggesting that digestibility was the governing factor of intake (Gherardi, et al., 1992).

It is well understood that sufficient amounts of coarse fiber is necessary to maintain proper rumen fermentation and function (Yang et al., 2001). peNDF is believed to be that portion of a diet that stimulates chewing activity and results in the formation of the rumen mat. One animal response used to measure peNDF is TC expressed as minutes per kilogram of NDFI. As particle size of the ration increases the peNDF content is believed to also increase, resulting in elevated TC, salivary buffer secretion and ruminal $\mathrm{pH}$ (Mertens, 2000). In the current study, diets of very different particle size were fed and although peNDF content of diets numerically increased with increasing particle size, differences were not significant. In contrast, percent of large particles $(>19.0 \mathrm{~mm})$ significantly increased and resulted in linear increases of TC an effect similar to that reported by others (Krause et al., 2002). Although we originally believed that trends in TC would also result in similar trends in rumen $\mathrm{pH}$, a quadratic effect was observed with diets of intermediate particle size having highest values, indicating that factors other than TC influence rumen $\mathrm{pH}$. Even though shortest particle size resulted in lowest TC, higher acid production, presumably less salivary secretion and lower mean rumen $\mathrm{pH}$, highest chewing activity in animals consuming diets of longest particle size was also paired with low mean $\mathrm{pH}$. Although higher rumen $\mathrm{pH}$ is indicative of rations resulting in higher ruminating activity, it is also highly responsive to the introduction of new substrate from the consumption of meals. We suggest that the different meal patterns with animals consuming excessively long rations may have resulted in a marked decrease in rumen $\mathrm{pH}$ that characteristically persisted for several hours before recovery to original levels (Le Liboux and Peyraud, 1999). Related to this was the observation that highest NDF digestibility occurred on the shortest diet that also resulted in lowest mean rumen $\mathrm{pH}$. This was somewhat surprising given that it is commonly believed that decreased $\mathrm{pH}$ lowers fiber digestion (Russell and Wilson, 1996). Although we cannot completely explain this effect, we speculate that $\mathrm{pH}$ did not reach the point, nor spend enough time at that point, necessary to impede activity of cellulolytic bacteria. Thus, even though it has been suggested that the predominant species of these bacteria do not grow below 6.0, we speculate some fiber digestion persisted, furthermore even though $\mathrm{SH}$ rations resulted in a rumen $\mathrm{pH}$ below 6.0 , it was short in duration.

Practically, it is useful to note that the amount of feed $>19.0-\mathrm{mm}$ is a more accurate indicator of chewing activity than peNDF, when estimated by the PSPS. Although the additional sieve measuring $1.18-\mathrm{mm}$ was not useful in predicting chewing activity, its application in measuring particle size of diets is warranted as TMR's typically contain 40 to $60 \%$ concentrate, most of which passes though the $8.0-\mathrm{mm}$ screen. Although the PSPS has resulted in a useful analytical method for measurement of particle size, further partitioning of smaller particles will more accurately describe sample fineness (Kononoff et al., 2003). Although demonstrated by this study, reducing haylage particle size decreased time spent chewing, the dataset was small, consisting of only 32 observations. As a result of these observations, further work should be carried out in attempt to further examine the relationship between particle size measurements using the PSPS and chewing activity.

Because saliva contains important buffers for the rumen environment, it is believed that the ability of a diet to stimulate chewing activity is critical in the regulation of ruminal $\mathrm{pH}$ levels. Our data suggests that ration particle size may result in large effects on TC; however, only small changes in rumen $\mathrm{pH}$ were observed. Recently Yang et al. (2001) noted that contribution of increased total daily saliva output due to increased TC on rumen $\mathrm{pH}$ is often overestimated. Although reduced particle size may decrease TC, changes in total saliva production are small (approximately 4\%), as resting saliva secretion will increase (Yang et al., 
2001). It therefore seems likely that the physical characteristics of the feed may have a smaller influence on rumen $\mathrm{pH}$ than we originally hypothesized. This suggestion is consistent with Allen, (1997) who noted that variation of rumen degradable organic matter (RDOM) may have a greater effect than particle size on the variation of $\mathrm{pH}$. Furthermore, our data suggests that the proportion of NDF $\geq 1.18 \mathrm{~mm}$ may not differ in rations containing forage of different cut length and as a result, when used alone, is a poor measurement of effective fiber. More specifically, accounting for larger particles in the ration may result in a more accurate estimate in the ability of the ration to stimulate TC and accounting for RDOM may have greater effects on the variation of rumen $\mathrm{pH}$.

Total milk yield, FCM, fat percentage and yield were not significantly affected by particle size reduction; however, a quadratic decrease was observed for percent milk protein but not yield. Although our original hypothesis speculated that milk fat percentage would increase with increasing particle size as observed by Grant et al. (1990) and Fisher et al. (1994), no significant effect was observed, similar to the results of Colenbrander et al (1991) and Belyea et al. (1989). The use of milk fat as a measure of fiber effectiveness has been questioned, especially for cows in early lactation, which are less responsive to dietary changes (Allen, 1997). The lack of response of milk fat to reduced particle size may also be due to the fact that rations met NRC requirements. It has been suggested that depressions in milk fat are more likely when NDF is below minimum requirements (Beauchemin and Rode, 1997).

Based on herd averages, mean average milk production $(35.5 \mathrm{~kg})$ and percent milk protein $(2.9 \%)$ were below that expected. All diets were evaluated using the NRC (2001) model for nutrient requirements of dairy cattle. Based on simulations, cows were predicted to consume $22 \mathrm{~kg}$ of feed containing $1.62 \mathrm{Mcal} / \mathrm{kg}$ of $\mathrm{NE}_{\mathrm{L}}$, resulting in an $\mathrm{NE}_{\mathrm{L}}$ and $\mathrm{MP}$ allowable milk of 38.0 and $32.3 \mathrm{~kg}$ respectively. Based on the simulation and recommendations of Schwab et al. (1996), experimental diets were adequate for flow of LYS and MET into the duodenal digesta pool (15 and 5\% of the total essential amino acid (EAA) pool) but RDP balance was in slight excess $(672 \mathrm{~g} / \mathrm{d})$ while RUP was deficient $(-182 \mathrm{~g} / \mathrm{d})$. Taken together this suggests that intake of $\mathrm{NE}_{\mathrm{L}}$ was not limiting and is supported by the observation that plasma NEFA levels were below $200 \mu \mathrm{eq} / \mathrm{L}$ across treatments. It is possible that milk production may have been in part limited due to the cost of metabolizing excess RDP, but more likely due to inadequate RUP in the ration (Schwab, 2002).

Published studies are only beginning to report particle size distributions based on measurements using the
PSPS, thus making recommendations difficult. Current NRC (2001) recommendations state that a minimum mean particle length of $3 \mathrm{~mm}$ for alfalfa diets is necessary to maintain rumen $\mathrm{pH}$, chewing activity, and milk fat percentage, however this recommendation is based on measurements using a vertical sieve shaker containing a profile of wire mesh sieves between 0.30 and $9.5 \mathrm{~mm}$. Because differences between methods of measurements have been reported and the method of measurement is more applicable to spherical shaped particles, this recommendation is not applicable to measurements made by the PSPS (Murphy and Zhu, 1997). Results of the current study suggest that alfalfa haylage based rations containing at least $30.0 \%$ NDF with $3.0 \%$ of the particles $>19.0 \mathrm{~mm}$ may be consumed in greater amounts, more rapidly, and fermented more extensively than those of longer particle size, and that passage rates did not reduce either fermentation or digestibility (Van Soest, 1994). Although further work is needed to evaluate possible interactions between particle size and ration NDF or NSC level on chewing activity and rumen $\mathrm{pH}$ this study suggests that peNDF is not an accurate indicator when estimated by the PSPS.

\section{CONCLUSIONS}

In the present study, reducing forage particle size increased DMI of TMR of dairy cattle in early lactation. Although chewing activity was closely related to forage particle size, effects on rumen $\mathrm{pH}$ were small, indicating factors other than particle size are critical in regulation when ration NDF meets recommended levels. Feeding alfalfa based rations with $3 \%$ compared to $>30 \%$ of the particles $\geq 19.0 \mathrm{~mm}$ increased DMD 3.4\%, increased total VFA concentration $13.3 \mathrm{mM} / \mathrm{L}$, and resulted in animals consuming $3.3 \mathrm{~kg}$ more and did not affect milk fat.

\section{ACKNOWLEDGMENTS}

This research was supported in part by USDA special grant no. 97-34281-4590. The assistance with assays and sample collection by M. Long is much appreciated. Our appreciation to students A. Gehman, T. Ross, A. Hess, K. Harvatine, N. Saloman, E. Samras, S. Rodriguez, H. Lehman, T. Haltman, B. Zary, and A. Zeladonis for feed preparation, sample collection, and analysis.

\section{REFERENCES}

Allen, M. S. 1997. Relationships between fermentation acid production in the rumen and the rumen and the requirement for physically effective fiber. J. Dairy Sci. 80:1447-1462.

Allen, M. S. 2000. Effects of diet on short term regulation of feed intake by lactating dairy cows. J. Dairy Sci. 83: 1598-1624. 
ASAE. 2001. S424. Method of determining and expressing particle size of chopped forage materials by sieving. Standards. Am. Soc. Agric. Eng., St. Joseph, MI.

Association of Official Analytical Chemists. 1990. Official methods of analysis. 15th Edition. AOAC, Arlington, VA.

Balch, C. C. 1971. Proposal to use time spent chewing as an index of extent to which diets for ruminants possess the physical property of fibrousness characteristics of roughages. Br. J. Nutr. 26:383-389.

Beauchemin, K. A., and L. M. Rode. 1997. Minimum versus optimum concentrations of fiber in dairy cows diets based on barley silage and concentrates of barley and corn. J. Dairy Sci. 80:1629-1639.

Beauchemin, K. A., L. M. Rode, and M. V. Eliason. 1997. Chewing activities and milk production of dairy cows fed alfalfa as hay, silage, or dried cubes or silage. J. Dairy Sci. 80:324-333.

Belyea, R. L., F. A. Martz, and G. A. Mbagaya. 1989. Effect of particle size of alfalfa hay on intake, digestibility, milk yield, and ruminal cell wall of dairy cattle. J. Dairy Sci. 72:958-963.

Broderick, G. A. and J. H. Kang. 1980. Automated simultaneous determination of ammonia and total amino acids in ruminal fluid and in vitro media. J. Dairy Sci. 63:64-75.

Chesson, A., C. W. Forsberg, and E. Grenet. 1995. Improving the digestion of plant cell walls and fibrous feeds. Pages 249-277 in Recent developments in the nutrition of herbivores, Proceedings of the 5th International Symposium on the Nutrition of Herbivores, INRA, Paris. M. Journet, E. Grenet, M. H. Farce, M. Theriez, and C. Demarquilly. Eds.

Colenbrander, V. F., C. H. Noller, and R. J. Grant. 1991. Effect of fiber content and particle size of alfalfa silage on performance and chewing behavior. J. Dairy Sci. 74:2681-2690.

Fischer, J. M., J. G. Buchanan-Smith, C. Campbell, D. G. Grieve, and O. B. Allen. 1994. Effects of forage particle size and long hay for cows fed total mixed rations based on alfalfa and corn. J. Dairy Sci. 77:217-229.

Gherardi, S.G., R.C. Kellaway, and J.L Black. 1992. Effect of forage particle length on digesta load, packing density and voluntary feed intake by sheep. Aust. J. Agric. Res. 43:1321-1336.

Grant, R. J., V. F. Colenbrander, and D. R. Mertens. 1990. Milk fat depression in dairy cows: role of silage particle size. J. Dairy. Sci. 73:1834-1842.

Grovum, W. L., and V. J. Williams. 1973. Rate of passage of digesta in sheep. 3. Differential rates of passage of water and dry matter from the reticulo-rumen, abomasums, and caecum and proximal colon. Br. J. Nutr. 30:231-236.

Hart, S. P., and C. E. Polan. 1984. Simultaneous extraction and determination of ytterbium and cobalt ethylenediamin-tetra-acetate complex in feces. J. Dairy Sci. 67:888-892.

Heinrichs, A. J., D. R. Buckmaster, and B. P. Lammers. 1999. Processing, mixing, and particle size reduction of forages for dairy cattle. J. Anim. Sci. 77:180-186.

Jaster, E. H., and M. R. Murphy. 1983. Effects of varying particle size of forage and digestion and chewing behavior of dairy heifers. J. Dairy Sci. 66:802-810.

Kertz, A. F., L. F. Reutzel, and G. M. Thomson. 1991. Dry matter intake from parturition to midlactation. J. Dairy Sci. 74:22902295.

Kononoff, P. J., A. J. Heinrichs, and D. A. Buckmaster. 2003. Modification of the Penn State forage and TMR separator and the effects of moisture content on its measurements. J. Dairy Sci. In Press.

Krause, K. M., D. K. Combs, and K. A. Beauchemin. 2002. Effects of forage particle size and grain ferment ability in midlactation cows. II. Ruminal pH and Chewing activity. J. Dairy Sci. 85:1947-1957.
Lammers, B. P., D. R. Buckmaster, and A. J. Heinrichs. 1996. A simplified method for the analysis of particle sizes of forage and total mixed rations. J. Dairy Sci. 79:922-928.

Le Liboux, S., and J. L. Peyraud. 1999. Effect of forage particle size and feeding frequency on fermentation patterns and sites and extent of digestion in dairy cows fed mixed diets. Anim. Feed. Sci. Tech. 76:297-319.

Lykos, T., G. A. Varga, and D. Casper. 1997. Varying degradation rates of total nonstructural carbohydrates: effects on ruminal fermentation, blood metabolites, and milk production and composition in high producing Holstein cows. J. Dairy Sci. 80:33413355.

Mertens, D. R. 1997. Creating a system for meeting the fiber requirements of dairy cattle. J. Dairy Sci. 80:1463-1482.

Mertens, D. R. 2000. Physically effective NDF and its use in dairy rations explored. Feedstuffs Pages 11-14, April 10, 2000.

Murphy, M. R., and J. S. Zhu. 1997. A comparison of methods to analyze particle size as applied to alfalfa hay, corn silage, and concentrate mix. J. Dairy Sci. 80:2932-2938.

National Research Council (NRC). 2001. Nutrient Requirements of Dairy Cattle. 7th Rev. Ed. Natl. Acad. Sci. (Washington DC),

Norgaard, P. 1983. Saliva secretion and acid-base status of ruminants: A review. Acta. Vet. Scand. Suppl. 89:93-100.

Poppi, D. P., R. E. Hendrickson, and D. J. Minson. 1985. The relative resistance to escape of leaf and stem particles from the rumen of cattle. J. Agric. Sci. 105:9-14.

Rodrigue, C. B., and N. N. Allen. 1960. The effect of fine grinding of hay on ration digestibility, rate of passage, and milk fat content of milk. Can. J. Anim. Sci. 40:23-29.

Russell, J. B., and D. B. Wilson. 1996. Why are ruminal cellulolytic bacteria unable to digest cellulose at low pH? J. Dairy Sci. 79:1503-1509

Rutter, S. M., R. A. Champion, and P. D. Penning. 1997. An automatic system to record foraging behavior in free-ranging ruminants. Appl. Anim. Behav. Sci. 54:185-195.

SAS/STAT. 1999. User's Guide, Version 8.0. SAS Inst., Inc., Cary, NC.

Schwab, C. G. 1996. Amino acids nutrition of the dairy cow: Current status. Pages 184-198 in Proc. Cornell Nutr. Conf., Ithaca, NY.

Schwab, C.G. 2002. Using the 2001 dairy NRC to optimize the use of dietary protein for milk protein. Pages 11-19 in Proc. Mid. So. Rum. Nutr. Conf. Arlington, TX.

Smith, D. 1981. Removing and analyzing carbohydrates from plant tissue. Wisconsin Agric. Exp. Stn. Rep. No. R2107, Madison.

Sudweeks, E. M., L. O. Ely, D. R. Mertens, and L. R. Sisk. 1981. Assessing minimum amounts and form of roughage in ruminant diets: Roughage value index system. J. Dairy Sci. 53:406-411.

Van Soest, P. J., J. B. Robertson, and B. A. Lewis. 1991. Symposium: Carbohydrate methodology, metabolism, and nutritional implications in dairy cattle. Methods for dietary fiber, neutral detergent fiber and non-starch polysaccharides in relation to animal nutrition. J. Dairy Sci. 74:3583-3597.

Weiss, W. P., H. R. Conrad, and N. R. S. Pierre. 1992. A theoretically based model for predicting total digestible nutrient values of forages and concentrates. Anim. Feed Sci. Technol. 39:95-110.

Woodford, S. T., and M. R. Murphy 1988. Effect of physical form of forage on chewing activity, dry matter intake, and rumen function of dairy cows in early lactation. J. Dairy Sci. 71:674-686.

Yang, W. Z., K. A. Beauchemin, and L. A. Rode. 2001. Effects of grain processing, forage to concentrate ration, and forage particle size on rumen $\mathrm{pH}$ and digestion by dairy cattle. J. Dairy Sci. $84: 2203-2216$.

Yang, C. M. J., and G. A. Varga. 1989. Effect of three concentrate feeding frequencies on rumen protozoa, rumen digesta kinetics, and milk yield in dairy cows. J. Dairy Sci. 72:950-957. 